\title{
Selective Double Hydrosilylation of Nitriles Catalyzed by an Iron Complex Containing Indium Trihalide
}

\author{
Masaki Ito, Masumi Itazaki, Hiroshi Nakazawa
}

\begin{tabular}{|c|l|}
\hline Citation & ChemCatChem, 8(21); 3323-3325 \\
\hline Issue Date & $2016-11-08$ \\
\hline Type & Journal Article \\
\hline Textversion & Author \\
\hline Rights & $\begin{array}{l}\text { This is the peer reviewed version of the following article: ITO, M., ITAZAKI, M., } \\
\text { \& NAKAZAWA, H. (2016). Selective Double Hydrosilylation of Nitriles Catalyzed } \\
\text { by an Iron Complex Containing Indium Trihalide. ChemCatChem. 8, 3323-3325., } \\
\text { which has been published in final form at https://doi.org/10.1002/cctc.201600940. } \\
\text { This article may be used for non-commercial purposes in accordance with Wiley } \\
\text { Terms and Conditions for Self-Archiving. }\end{array}$ \\
\hline DOI & \begin{tabular}{l}
$10.1002 / c c t c .201600940$ \\
\hline
\end{tabular}
\end{tabular}

\author{
Self-Archiving by Author(s) \\ Placed on: Osaka City University
}




\title{
Selective Double-Hydrosilylation of Nitriles Catalyzed by an Iron Complex Containing Indium Trihalide
}

\author{
Masaki Ito, Masumi Itazaki, and Hiroshi Nakazawa*
}

\begin{abstract}
Selective double-hydrosilylation was achieved using tertiary and secondary silanes with an excess of organonitriles $(\mathrm{RC} \equiv \mathrm{N}(\mathrm{R}=$ alkyl, aryl) $)$, in the presence of a catalytic amount of triirondodecacarbonyl $\left(\mathrm{Fe}_{3}(\mathrm{CO})_{12}\right)$ and indium trichloride $\left(\mathrm{InCl}_{3}\right)$. This reaction was also catalyzed by an iron complex containing indium trihalide $\left[\mathrm{Fe}(\mathrm{MeCN})_{6}\right]\left[\mathrm{Fe}(\mathrm{CO})_{4}\left(\ln \mathrm{X}_{3}\right)_{2}\right]$, prepared by the reaction of $\mathrm{Fe}_{3}(\mathrm{CO})_{12}$ with $\ln \mathrm{X}_{3}(\mathrm{X}=\mathrm{Cl}, \mathrm{Br}, \mathrm{I})$. This is a novel report of the combination of a transition metal complex and an indium source in organic synthesis.
\end{abstract}

Transformations of organonitriles into other organic compounds catalyzed by a transition metal complex have been reported, e.g. $\mathrm{C}-\mathrm{CN}$ bond cleavage, ${ }^{[1]}$ hydrosilylation of $\mathrm{C} \equiv \mathrm{N}$ bond. ${ }^{[2]} \mathrm{We}$ previously reported the synthesis of silyl cyanide through $\mathrm{C}-\mathrm{CN}$ bond activation of organonitriles by an iron catalyst. ${ }^{[3]}$

Among these reactions, hydrosilylation of a $\mathrm{C} \equiv \mathrm{N}$ triple bond is one of the most atom-efficient reactions because the reaction theoretically produces no by-products. In the reaction of $\mathrm{RC} \equiv \mathrm{N}$ with hydrosilane $\mathrm{R}_{3}{ }_{3} \mathrm{SiH}$, the expected products are the silylimine $\left(\mathrm{RHC}=\mathrm{NSiR}_{3}{ }_{3}\right)$ and disilyl amine $\left(\mathrm{RH}_{2} \mathrm{C}-\mathrm{N}\left(\mathrm{SiR}_{3}\right)_{2}\right)$, which are formed by single ${ }^{[4 a-d]}$ and double ${ }^{[4-k]}$ hydrosilylation, respectively (Scheme 1). These $\mathrm{N}$-silylated compounds are highly useful precursors of $\mathrm{N}$-containing organic compounds ${ }^{[5]}$ and siliconcontaining polymers. ${ }^{[6]}$ Moreover, hydrosilylation of a $\mathrm{C} \equiv \mathrm{N}$ triple bond is an effective method for the reduction of nitriles. ${ }^{[7]}$ Only a few examples of double hydrosilylation catalyzed by a transition metal complex have been reported. ${ }^{[4 \mathrm{e}-k]}$ In addition, catalytic hydrosilylations of nitriles without a transition metal catalyst have been reported; in 2015, Chang's group reported that $B\left(C_{6} F_{5}\right)_{3}$ exhibited catalytic activity for chemoselective hydrosilylation of conjugated nitriles. ${ }^{[8]}$ Unfortunately, the catalyst is moisture sensitive and expensive.

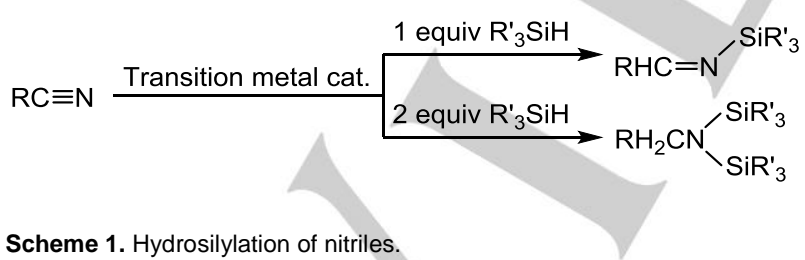

[a] M. Ito, Dr. M. Itazaki, Prof. Dr. H. Nakazawa

Department of Chemistry, Graduate School of Science

Osaka City University

Sumiyoshi-ku, Osaka 558-8585, Japan

E-mail: nakazawa@sci.osaka-cu.ac.jp

Supporting information for this article is given via a link at the end of the document.
Most catalytic reactions for hydrosilylation of nitriles require an excess of hydrosilane in order to afford the disilyl-amine selectively. Here, we report a new catalytic system for the selective double-hydrosilylation of nitriles using an iron-based catalyst, without excess hydrosilane.

Acetonitrile $(4.0 \mathrm{mmol}), \mathrm{Me}_{2} \mathrm{PhSiH}(0.80 \mathrm{mmol}), \mathrm{Fe}_{3}(\mathrm{CO})_{12}$ $(0.027 \mathrm{mmol})$, and $\mathrm{InCl}_{3}(0.080 \mathrm{mmol})$ were charged into a sealed glass tube under a dry nitrogen atmosphere, and the solution was heated at $80^{\circ} \mathrm{C}$ for $24 \mathrm{~h}$ (Scheme 2). After removal of volatile materials under reduced pressure, the disilyl amine $\mathrm{MeCH}_{2}-\mathrm{N}\left(\mathrm{SiMe}_{2} \mathrm{Ph}\right)_{2}$ was obtained in $78 \%$ yield by extraction with $n$-hexane and drying in vacuo (Table 1 , entry 1 ). Unexpectedly, double-hydrosilylation had occurred selectively, even if an excess of nitrile over hydrosilane was used. The ${ }^{1} \mathrm{H}$ NMR spectrum of the reaction mixture revealed that the silyl imine was not formed. A deuterium labeling experiment using $\mathrm{CD}_{3} \mathrm{CN}$ in place of $\mathrm{CH}_{3} \mathrm{CN}$ afforded $\mathrm{CD}_{3} \mathrm{CH}_{2}-\mathrm{N}\left(\mathrm{SiMe} \mathrm{P}_{2} \mathrm{Ph}\right)_{2}$ in $73 \%$ yield. To the best of our knowledge, there are no previous reports of an iron complex combined with an indium source used in organic synthesis. ${ }^{[9]}$

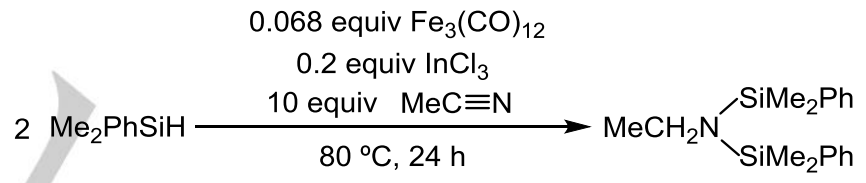

Scheme 2. Double-hydrosilylation of acetonitrile promoted by $\mathrm{Fe}_{3}(\mathrm{CO})_{12}$ with $\mathrm{InCl}_{3}$.

$\mathrm{Fe}_{3}(\mathrm{CO})_{12}$ or $\mathrm{InCl}_{3}$ when used separately for the doublehydrosilylation of acetonitrile with $\mathrm{Me}_{2} \mathrm{PhSiH}$ showed no catalytic activity (Table 1, entries 2, 3). $\left[\mathrm{Fe}(\mathrm{MeCN})_{6}\right]\left[\mathrm{Fe}(\mathrm{CO})_{4}\left(\operatorname{In} \mathrm{X}_{3}\right)_{2}\right]$ prepared from $\mathrm{Fe}_{3}(\mathrm{CO})_{12}$ and $\ln X_{3}{ }^{[10,11]}$ exhibited catalytic activity (entries 4-6), with $\left[\mathrm{Fe}(\mathrm{MeCN})_{6}\right]\left[\mathrm{Fe}(\mathrm{CO})_{4}\left(\mathrm{InCl}_{3}\right)_{2}\right]$ showing the highest activity among them. When the amount of $\left[\mathrm{Fe}(\mathrm{MeCN})_{6}\right]\left[\mathrm{Fe}(\mathrm{CO})_{4}\left(\mathrm{InCl}_{3}\right)_{2}\right]$ was reduced from 5 to $1 \mathrm{~mol} \%$ or when THF was used as a solvent, the yield was greatly diminished (entries 7, 8). Further, the reaction did not proceed at room temperature (entry 9). When $\left[\mathrm{Fe}(\mathrm{MeCN})_{6}\right]\left[\mathrm{PF}_{6}\right]_{2}$ was used as a catalyst, hydrosilylation was not observed (entry 10), but the reaction proceeded when $[\mathrm{PPN}]_{2}\left[\mathrm{Fe}(\mathrm{CO})_{4}\left(\mathrm{InCl}_{3}\right)_{2}\right]$ was used (entry 11). It was therefore concluded that the anionic part of $\left[\mathrm{Fe}(\mathrm{MeCN})_{6}\right]\left[(\mathrm{CO})_{4} \mathrm{Fe}\left(\operatorname{InCl}_{3}\right)_{2}\right]$ acted as the catalyst in doublehydrosilylation. The different activities of the iron-indium complexes in entries 4 and 11 may result from the degree of stabilization by the cation. 
Table 1. Catalytic double-hydrosilylation of acetonitrile with $\mathrm{Me}_{2} \mathrm{PhSiH} .{ }^{[\mathrm{a}]}$

\begin{tabular}{|c|c|c|}
\hline entry & cat. [amount $(\mathrm{mol} \%)]^{[\mathrm{b}]}$ & yield $(\%)^{[c]}$ \\
\hline 1 & $\mathrm{Fe}_{3}(\mathrm{CO})_{12}(3.3)+\operatorname{lnCl}_{3}(10)$ & 78 \\
\hline 2 & $\mathrm{Fe}_{3}(\mathrm{CO})_{12}(3.3)$ & 0 \\
\hline 3 & $\operatorname{lnCl}_{3}(10)$ & 0 \\
\hline 4 & {$\left[\mathrm{Fe}(\mathrm{MeCN})_{6}\right]\left[(\mathrm{CO})_{4} \mathrm{Fe}\left(\mathrm{InCl}_{3}\right)_{2}\right](5)$} & 85 \\
\hline 5 & {$\left[\mathrm{Fe}(\mathrm{MeCN})_{6}\right]\left[(\mathrm{CO})_{4} \mathrm{Fe}\left(\mathrm{InBr}_{3}\right)_{2}\right](5)$} & 56 \\
\hline 6 & {$\left[\mathrm{Fe}(\mathrm{MeCN})_{6}\right]\left[(\mathrm{CO})_{4} \mathrm{Fe}\left(\mathrm{InI}_{3}\right)_{2}\right](5)$} & 21 \\
\hline 7 & {$\left[\mathrm{Fe}(\mathrm{MeCN})_{6}\right]\left[(\mathrm{CO})_{4} \mathrm{Fe}\left(\mathrm{InCl}_{3}\right)_{2}\right](1)$} & trace \\
\hline $8^{[d]}$ & {$\left[\mathrm{Fe}(\mathrm{MeCN})_{6}\right]\left[(\mathrm{CO})_{4} \mathrm{Fe}\left(\mathrm{InCl}_{3}\right)_{2}\right](5)$} & trace \\
\hline $9^{[e]}$ & {$\left[\mathrm{Fe}(\mathrm{MeCN})_{6}\right]\left[(\mathrm{CO})_{4} \mathrm{Fe}\left(\mathrm{InCl}_{3}\right)_{2}\right](5)$} & 0 \\
\hline 10 & {$\left[\mathrm{Fe}(\mathrm{MeCN})_{6}\right]\left[\mathrm{PF}_{6}\right]_{2}(5)$} & 0 \\
\hline 11 & {$[\mathrm{PPN}]_{2}\left[(\mathrm{CO})_{4} \mathrm{Fe}(\mathrm{InCl})_{2}\right](5)$} & 35 \\
\hline
\end{tabular}

[a] $\mathrm{Me}_{2} \mathrm{PhSiH} /$ acetonitrile $=0.8: 4.0 \mathrm{mmol}$. [b] Based on [ $\mathrm{Me}_{2} \mathrm{PhSiH}$ ]. [c] Isolated yield. [d] In THF (0.5 mL). [e] At room temperature.

To explore the scope of double-hydrosilylation reactions catalyzed by $\left[\mathrm{Fe}(\mathrm{MeCN})_{6}\right]\left[\mathrm{Fe}(\mathrm{CO})_{4}\left(\mathrm{InCl}_{3}\right)_{2}\right]$, several combinations of nitriles and hydrosilanes were examined (Table 2). Reactions were observed for the double-hydrosilylation of $\mathrm{Me}_{2} \mathrm{PhSiH}$ with $\mathrm{RC} \equiv \mathrm{N}$, where $\mathrm{R}=\mathrm{Me}$, Et, $\mathrm{iBu}, \mathrm{Pr}, \mathrm{Ph}, p$-Tol, $m$ Tol or 0 -Tol (entries 1-4, 6-9). In the case of propane nitrile (EtCN), the main product was $\mathrm{EtCH}_{2} \mathrm{~N}\left(\mathrm{SiMe}_{2} \mathrm{Ph}\right)_{2}$, with $\mathrm{MeCH}_{2} \mathrm{~N}\left(\mathrm{SiMe}_{2} \mathrm{Ph}\right)_{2}$ as a by-product (2\% NMR yield). The byproduct is believed to have formed from $\mathrm{MeCN}$, due to $\mathrm{EtCN} / \mathrm{MeCN}$ exchange on the cationic part of the catalyst (entry 2). The hydrosilylation was strongly influenced by steric effects of the substituent on the nitrile carbon; the yield decreased when using $\operatorname{PrCN}$ (entry 4), and no reaction was observed when using tBuCN (entry 5). Yields from tolunitrile decreased in the order $p$ $>m$->o-tolunitrile, presumably because of the increasing steric hindrance around the nitrile group (entries 7-9). Benzonitrile and $p$-tolunitrile gave the corresponding disilyl amines in similar yields (entries 6, 7). 4-PyCN was also converted into the corresponding disilyl amine, although the yield was low (entry 10). Nitriles containing electron-withdrawing substituents and $\mathrm{NC}\left(\mathrm{CH}_{2}\right)_{4} \mathrm{CN}$ did not undergo hydrosilylation (entries 11-13). Reactions were observed for the double-hydrosilylation of $\mathrm{Me}_{2} \mathrm{FcSiH}$ with $p$-TolCN and $\mathrm{MePhSiH}_{2}$ with $\mathrm{MeCN}$, giving the corresponding disilyl amines in $43 \%$ and $76 \%$ yields, respectively (entries 14,15 ). All disilyl amines obtained were characterized by ${ }^{1} \mathrm{H},{ }^{13} \mathrm{C}\left\{{ }^{1} \mathrm{H}\right\},{ }^{29} \mathrm{Si}\left\{{ }^{1} \mathrm{H}\right\} \quad \mathrm{NMR}, \mathrm{GC} / \mathrm{MS}$, and elemental analyses (see supporting information).
Table 2. Double-hydrosilylation of various nitriles with hydrosilanes catalyzed by an iron-indium complex. ${ }^{[a]}$

\begin{tabular}{|c|c|c|c|c|}
\hline entry & $\mathrm{RC} \equiv \mathrm{N}$ & $\mathrm{R}_{3}{ }_{3} \mathrm{SiH}$ & $\mathrm{RCH}_{2} \mathrm{~N}\left(\mathrm{SiR}_{3}{ }_{3}\right)_{2}$ & yield $^{[b]}$ \\
\hline 1 & $\mathrm{MeCN}$ & $\mathrm{Me}_{2} \mathrm{PhSiH}$ & $\mathrm{MeCH}_{2} \mathrm{~N}\left(\mathrm{SiMe}_{2} \mathrm{Ph}\right)_{2}(\mathbf{1})$ & 85 \\
\hline 2 & $\mathrm{EtCN}$ & $\mathrm{Me}_{2} \mathrm{PhSiH}$ & $\mathrm{EtCH}_{2} \mathrm{~N}\left(\mathrm{SiMe}_{2} \mathrm{Ph}\right)_{2}(\mathbf{2})$ & $65^{[c]}$ \\
\hline 3 & IBuCN & $\mathrm{Me}_{2} \mathrm{PhSiH}$ & $\mathrm{BuCH}_{2} \mathrm{~N}\left(\mathrm{SiMe}_{2} \mathrm{Ph}\right)_{2}(\mathbf{3})$ & 75 \\
\hline 4 & $\mathrm{iPrCN}$ & $\mathrm{Me}_{2} \mathrm{PhSiH}$ & $\mathrm{PrCH}_{2} \mathrm{~N}\left(\mathrm{SiMe}_{2} \mathrm{Ph}\right)_{2}(\mathbf{4})$ & 66 \\
\hline 5 & tBuCN & $\mathrm{Me}_{2} \mathrm{PhSiH}$ & - & - \\
\hline 6 & $\mathrm{PhCN}$ & $\mathrm{Me}_{2} \mathrm{PhSiH}$ & $\mathrm{PhCH}_{2} \mathrm{~N}\left(\mathrm{SiMe}_{2} \mathrm{Ph}\right)_{2}(\mathbf{5})$ & 54 \\
\hline 7 & $(p-\mathrm{Tol}) \mathrm{CN}$ & $\mathrm{Me}_{2} \mathrm{PhSiH}$ & $(p-\mathrm{Tol}) \mathrm{CH}_{2} \mathrm{~N}\left(\mathrm{SiMe}_{2} \mathrm{Ph}\right)_{2}(\mathbf{6})$ & 55 \\
\hline 8 & $(m-\mathrm{Tol}) \mathrm{CN}$ & $\mathrm{Me}_{2} \mathrm{PhSiH}$ & $(m-\mathrm{Tol}) \mathrm{CH}_{2} \mathrm{~N}\left(\mathrm{SiMe}_{2} \mathrm{Ph}\right)_{2}(7)$ & 49 \\
\hline 9 & $(0-\mathrm{Tol}) \mathrm{CN}$ & $\mathrm{Me}_{2} \mathrm{PhSiH}$ & $(0-\mathrm{Tol}) \mathrm{CH}_{2} \mathrm{~N}\left(\mathrm{SiMe}_{2} \mathrm{Ph}\right)_{2}(\mathbf{8})$ & 41 \\
\hline 10 & $(4-\mathrm{Py}) \mathrm{CN}$ & $\mathrm{Me}_{2} \mathrm{PhSiH}$ & $(4-\mathrm{Py}) \mathrm{CH}_{2} \mathrm{~N}\left(\mathrm{SiMe}_{2} \mathrm{Ph}\right)_{2}(\mathbf{9})$ & 21 \\
\hline 11 & $\mathrm{CCl}_{3} \mathrm{CN}$ & $\mathrm{Me}_{2} \mathrm{PhSiH}$ & - & - \\
\hline 12 & $\left(\mathrm{C}_{6} \mathrm{~F}_{5}\right) \mathrm{CN}$ & $\mathrm{Me}_{2} \mathrm{PhSiH}$ & - & - \\
\hline 13 & $\mathrm{NC}\left(\mathrm{CH}_{2}\right)_{4} \mathrm{CN}$ & $\mathrm{Me}_{2} \mathrm{PhSiH}$ & - & - \\
\hline 14 & $(p-\mathrm{Tol}) \mathrm{CN}$ & $\mathrm{Me}_{2} \mathrm{FcSiH}$ & $(p-\mathrm{Tol}) \mathrm{CH}_{2} \mathrm{~N}\left(\mathrm{SiMe}_{2} \mathrm{Fc}\right)_{2}(\mathbf{1 0})$ & 43 \\
\hline 15 & $\mathrm{MeCN}$ & $\mathrm{MePhSiH}_{2}$ & $\mathrm{MeCH}_{2} \mathrm{~N}(\mathrm{SiMePhH})_{2}(\mathbf{1 1})$ & 76 \\
\hline
\end{tabular}

[a] See supporting information for details of reaction conditions. [b] Isolated yield. [c] The relatively low reaction yield of $\mathrm{EtCH}_{2} \mathrm{~N}\left(\mathrm{SiMe}_{2} \mathrm{Ph}\right)_{2}$ is caused by the difficulty in the removal of $\mathrm{MeCH}_{2} \mathrm{~N}\left(\mathrm{SiMe}_{2} \mathrm{Ph}\right)_{2}$ produced as a by-product in this reaction, by distillation because of the similar boiling points.

In order to obtain insight into the mechanism of the $\left[\mathrm{Fe}(\mathrm{MeCN})_{6}\right]\left[\mathrm{Fe}(\mathrm{CO})_{4}\left(\mathrm{InCl}_{3}\right)_{2}\right]$ system, we examined two reactions. First, we carried out the reaction using $\mathrm{InCl}_{3}$ as an additive in excess (eq. i) and found that no hydrosilylation occurred. We therefore concluded that the dissociation of $\mathrm{InCl}_{3}$ is important in our system.

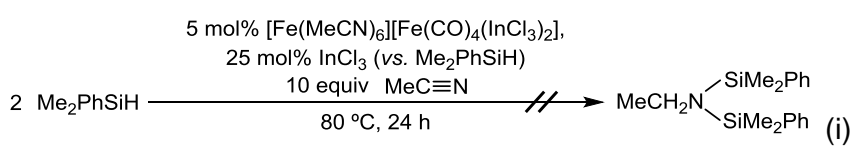

We suspected that $\mathrm{InCl}_{3}$ eliminated from the catalyst precursor reacts with hydrosilane to give indium hydride $\mathrm{HInCl}_{2}$, as reported by Baba and co-workers. ${ }^{[12]}$ Moreover, they reported that $\mathrm{HInX}_{2}$ acts as a radical. ${ }^{[13]}$ We examined our reaction system in the presence of TEMPO as a radical scavenger and found that the formation of disilyl amine was suppressed (eq. ii). 
We therefore concluded that $\mathrm{HInCl}_{2}$ was involved in the reaction pathway.

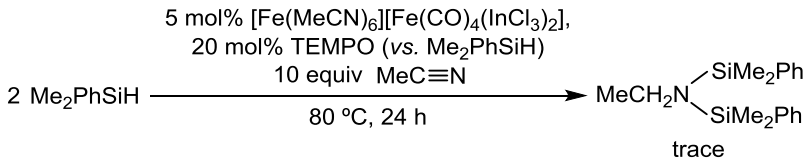

Based on the observations mentioned above, we tentatively propose a catalytic cycle, as depicted in Scheme 3. First, one indium ligand in $\left[\mathrm{Fe}(\mathrm{CO})_{4}\left(\mathrm{InCl}_{3}\right)_{2}\right]^{2-}$ dissociates and monoindiumiron species $\mathbf{A}$ is generated. Then, the released indium trichloride reacts with hydrosilane to give indium hydride and chlorosilane. One of $\mathrm{CO}$ ligands in $\mathbf{A}$ is replaced by the nitrile used to give $\mathbf{B}$. Then, $\mathbf{B}$ reacts with indium hydride to form indylimine complex $\mathbf{C}$. Intermediate $\mathbf{C}$ reacts with hydrosilane to give silylimine iron complex $\mathbf{D}$, which reacts further to give indylsilylamine complex E. Finally, E reacts with hydrosilane then the nitrile used to produce disilylamine and $\mathrm{HInCl}_{2}$ with regeneration of $\mathbf{B}$. We think that the silylimine in $\mathbf{D}$ does not dissociate readily from the iron center and/or $\mathbf{D}$ is extremely reactive toward $\mathrm{HInCl}_{2}$; therefore, selective disilyl amine formation is eventually achieved.

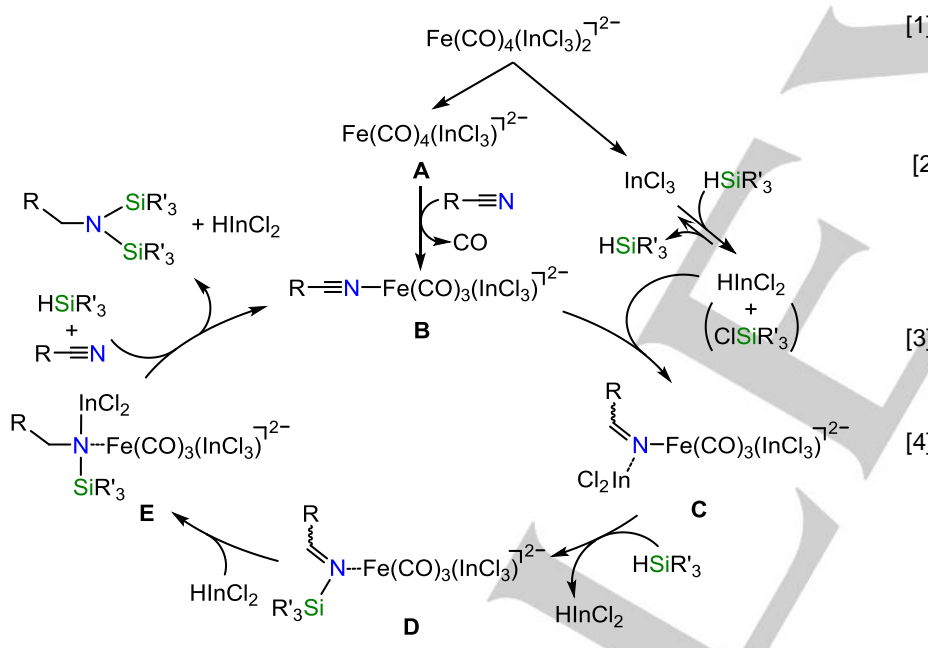

Scheme 3. Proposed catalytic cycle for the formation of a disilyl amine in the reaction of nitrile with hydrosilane promoted by $\left[\mathrm{Fe}(\mathrm{MeCN})_{6}\right]\left[\mathrm{Fe}(\mathrm{CO})_{4}\left(\mathrm{InCl}_{3}\right)_{2}\right]$

In summary, we have described an unprecedented selective double-hydrosilylation of organonitriles promoted by a combination of triirondodecacarbonyl $\mathrm{Fe}_{3}(\mathrm{CO})_{12}$ with indium trichloride $\quad \mathrm{InCl}_{3}$ Iron-indium complex $\left.\left[\mathrm{Fe}(\mathrm{MeCN})_{6}\right]\left[\mathrm{Fe}(\mathrm{CO})_{4}(\operatorname{InX})_{3}\right)_{2}\right]$ also showed catalytic activity. In our reaction system, only the double hydrosilylation product was obtained and no single hydrosilylation product was produced. Our catalytic system was applicable to various nitriles and hydrosilanes.

\section{Experimental Section}

General procedure for synthesis of disilyl amine derivatives in Table 2: Nitrile $(4.0 \mathrm{mmol})$ was treated with tertiary (or secondary) silane $(0.80$ $\mathrm{mmol})$ in the presence of iron-indium catalyst $\left[\mathrm{Fe}\left(\mathrm{CH}_{3} \mathrm{CN}\right)_{6}\right]\left[(\mathrm{CO})_{4} \mathrm{Fe}\left(\mathrm{InCl}_{3}\right)_{2}\right](36.5 \mathrm{mg}, 0.040 \mathrm{mmol})$ at $80{ }^{\circ} \mathrm{C}$ for $24 \mathrm{~h}$ under nitrogen atmosphere. After all volatile materials were removed under reduced pressure, the residue was extracted with $n$-hexane $(2 \mathrm{~mL}$ $\times 3$ ) and the filtrate was dried in vacuo to give the corresponding disilyl amine. Purified product was obtained by distillation using a Kugelrohr.

\section{Acknowledgements}

This work was supported by a Challenging Exploratory Research Grant (No. 15K13662), a Grant-in-Aid for Science Research Japan (C) (No. 16K05728), a Grant-in-Aid for Scientific Research on Innovative Area "Stimuli-responsive Chemical Species for the Creation of Function Molecules (No. 2408)"(JSPSKAKENHI Grant Number JP15H00957) from MEXT Japan, and the Sasakawa Scientific Research Grant from The Japan Science Society.

Keywords: Double-hydrosilylation • Nitrile • Iron catalyst • Indium halide

[1] a) F. Chen, T. Wang, N. Jiao, Chem. Rev. 2014, 114, 8613-8661; b) Y. Nakao, in Catalytic C-CN Bond Activation, (Ed.: G. Dong), Springe Berlin, 2014, 346, pp. 33-58; c) L. Souillart, N. Cramer, Chem. Rev. 2015, 115, 9410-9464

[2] a) B. Marciniec, J. Guliński, W. Urbaniak, Z. W. Kornetka, in Comprehensive Handbook on Hydrosilylation, (Ed. B. Marciniec), Pargamon, Oxford, 1992; b) D. Addis, S. Das, K. Junge, M. Beller, Angew. Chem. 2011, 123, 6128-6135; Angew. Chem. Int. Ed. 2011, 50, 6004-6011.

[3] a) H. Nakazawa, K. Kamata, M. Itazaki, Chem. Commun. 2005, 4004 4006; b) H. Nakazawa, M. Itazaki, K. Kamata, K. Ueda, Chem. Asian J. 2007, 2, 882-888.

a) T. Fuchigami, I. Igarashi, Jpn Patent Appl. JP11228579, 1999; b) A. Y. Khalimon, R. Simionescu, L. G. Kuzmina, J. A. K. Howard, G. I. Nikonov, Angew. Chem. 2008, 120, 7815-7818; Angew. Chem. Int. Ed. 2008, 47, 7701-7704; c) E. Peterson, A. Y. Khalimon, R. Simionescu, L. G. Kuzmina, J. A. K. Howard, G. I. Nikonov, J. Am. Chem. Soc. 2009 131, 908-909; d) D. V. Gutsulyak, G. I. Nikonov, Angew. Chem. 2010, 122, 7715-7718; Angew. Chem. Int. Ed. 2010, 49, 7553-7556; e) R. J. P. Corriu, J. J. E. Moreau, M. Pataud-Sat, J. Organomet. Chem. 1982, 228, 301-308; f) T. Murai, T. Sakane, S. Kato, Tetrahedron Lett. 1985, 26, 5145-5148; g) T. Murai, T. Sakane, S. Kato, J. Org. Chem. 1990, 55, 449-453; h) N. P. Reddy, Y. Uchimaru, H.-J. Lautenschlager, M. Tanaka, Chem. Lett. 1992, 45-48; i) A. M. Caporusso, N. Panziera, P. Pertici, E. Pitzalis, P. Salvadori, G. Vitulli, G. Martra, J. Mol. Catal. A 1999, 150, 275-285; j) J. Campos, M. Rubio, A. C. Esqueda, E. J. Carmona, Label Compd. Radiopharm 2012, 55, 29-38; k) A. J. Huckaba, T. K. Hollis, S. W. Reilly, Organometallics 2013, 32, 62486256.

[5] a) J. Barluenga, F. Aznar, C. Valdés, Angew. Chem. 2004, 116, 347 349; Angew. Chem. Int. Ed. 2004, 43, 343-345; b) K. Shimizu, Y Minami, O. Goto, H. Ikehira, T. Hiyama, Chem. Lett. 2014, 43, 438-440.

[6] a) I. Ojima in The Chemistry of Organic Silicon Compounds, Vol. 1 and 2 (Eds. S. Patai, Z. Rappoport), Wiley Interscience, New York, 1989, pp. 1479-1526; b) A. M. Tondreau, C. C. H. Atienza, K. J. Weller, S. A. Nye, K. M. Lewis, J. G. P. Delis, P. J. Chirik, Science 2012, 335, 567-570. 
[7] a) S. Das, B. Wendt, K. Möller, K. Junge, M. Beller, Angew. Chem. Int. Ed. 2012, 51, 1662-1666; b) C. Bornschein, S. Werkmeister, K. Junge M. Beller, New J. Chem. 2013, 37, 2061-2065.

[8] N. Gandhamsetty, J. Park, J. Jeong, S.-W. Park, S. Park, S. Chang, Angew. Chem. 2012, 124, 1694-1698; Angew. Chem. Int. Ed. 2015, 54, 6832-6836.

[9] Some examples of transition metal/indium catalysis have been reported previously. For example, see: a) A. P. Tyupaev, E. A. Timofeeva, G. V Isagulyants, Russ. Chem. Bull. 1982, 31, 1843-1847. b) Y. Kintaichi, M. Haneda, M. Inaba, H. Hamada, Catal. Lett. 1997, 48, 121-127. c) T. Tsuchimoto, S. Kamiyama, R. Negoro, E. Shirakawa, Y. Kawakami, Chem. Commun. 2003, 852-853. d) N. Sakai, K. Annaka, T. Konakahara, Org. Lett. 2004, 6, 1527-1530. e) Z. Liu, J. Hao, L. Fu, T. Zhu, J. Li, X. Cui, Appl. Catal., B 2004, 48, 37-48. f) R. B. Bedford, M. Betham, M. E. Blake, A. Garcés, S. L. Millar, S. Prashar, Tetrahedron 2005, 61, 9799-9807. g) B. M. Trost, A. Breder, Org. Lett. 2011, 13 398-401. h) R. Riveiros, R. Tato, J. P. Sestelo, L. A. Sarandeses, Eur. J. Org. Chem. 2012, 3018-3023. i) I. A. Witońska, M. J. Walock, P. Dziugan, S. Karski, A. V. Stanishevsky, Appl. Surf. Sci. 2013, 273, 330 342. j) T. Takanashi, M. Tamura, Y. Nakagawa, K. Tomishige, RSC Adv. 2014, 4, 28664-28672. k) J.-B. Xi, M.-L. Ma, W. Hu, Tetrahedron 2016, 72, 579-583.

[10] M. Itazaki, M. Ito, S. Nakashima, H. Nakazawa, Dalton Trans. 2016, 45, 1327-1330.

[11] A similar reaction using $\mathrm{Ru}_{3}(\mathrm{CO})_{12}$ in place of $\mathrm{Fe}_{3}(\mathrm{CO})_{12}$ afforded ruthenium indane complexes, fac- $\left[\mathrm{Ru}(\mathrm{NCMe})_{3}(\mathrm{CO})_{2}\left(\ln X_{3}\right)\right](\mathrm{X}=\mathrm{Cl}, \mathrm{Br})$. M. Itazaki, M. Ito, H. Nakazawa, Eur. J. Inorg. Chem. 2015, 2033-2036.

[12] I. Shibata, H. Kato, T. Ishida, M. Yasuda, A. Baba, Angew. Chem. 2004 116, 729-732; Angew. Chem. Int. Ed. 2004, 43, 711-714.

[13] K. Inoue, A. Sawada, I. Shibata, A. Baba, Tetrahedron Lett. 2001, 42, 4661-4663. 
Selective double-hydrosilylation was achieved using tertiary and secondary silanes with an excess of organonitriles $(\mathrm{RC} \equiv \mathrm{N}(\mathrm{R}=$ alkyl, aryl)), in the presence of a catalytic amount of triirondodecacarbonyl $\left(\mathrm{Fe}_{3}(\mathrm{CO})_{12}\right)$ and indium trichloride $\left(\mathrm{InCl}_{3}\right)$. This reaction was also catalyzed by an iron complex containing indium trihalide $\left[\mathrm{Fe}(\mathrm{MeCN})_{6}\right]\left[\mathrm{Fe}(\mathrm{CO})_{4}(\operatorname{lnX})_{3}\right)_{2}$, prepared by the reaction of $\mathrm{Fe}_{3}(\mathrm{CO})_{12}$ with $\ln X_{3}(X=C l, B r, I)$.
Masaki Ito, Masumi Itazaki, and Hiroshi Nakazawa*

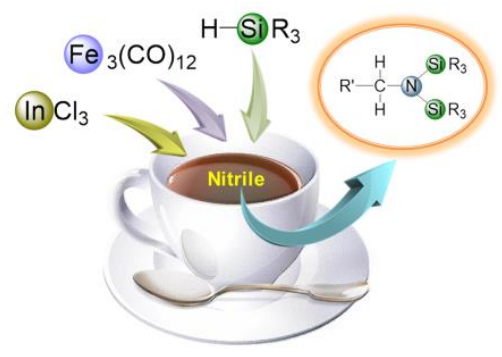

Selective Double-Hydrosilylation of Nitriles Catalyzed by an Iron Complex Containing Indium Trihalide 